\title{
Waste Management Facility Siting and Social Conflicts - the Case of Hungary
}

\author{
Szántó Richárd \\ Corvinus University of Budapest \\ Hungary
}

\section{Introduction}

Frank Popper was the first to have used the concept of LULU (Locally Unwanted Land Uses) in 1981. LULU may refer to low-cost housing, power plants, airports, wastewater treatment plants, prisons, open-cast mines, energy supply lines, motorways, dams, oil refineries, railway lines, landfills, cemeteries, amusement parks or pubs or military facilities (Popper, 1981). Almost every major regional development project (petrol station, car repair shop, motel, parking house, rent-a-car company etc.) behaves like a LULU, and often even facilities which at first sight seem to be desired by the community (office building, residential park, luxury hotel, hospital, assembly shop, port etc.) come to the fate of LULUs. It would be very difficult to describe by one word why these facilities sometimes provoke such extraordinary resistance. Fear from physical injuries may be a motive, the same as concern about the stigmatisation of the host settlement and the consequent drop in real estate prices. Some negative impacts are certain to occur (e.g. increase in air pollution and noise load near a newly completed motorway section), whereas others have a very low occurrence probability (such as the leakage of a nuclear waste repository, for example). The negative health or economic impacts may be accompanied by negative social impacts, such as the erosion of the social networks or the often irreversible alteration of the local cultures (Lesbirel, 2003). In the context of an international comparative survey of the motives of protest against the siting of low-level nuclear waste repositories, Anna Vári and her fellow researchers came to the conclusion that concerns about undesirable facilities typically fall into five categories: the opponents of the repositories expressed health and safety, economic, environmental and social as well as technical and decision-making-related concerns (Vári et al., 1991).

In addition to LULU, another commonly used acronym in connection with the siting of facilities of the above type is NIMBY, i.e. not in my backyard. For the purpose of completeness, let me mention that in addition to the two well-known acronyms (LULU and NIMBY), new ones have also appeared in the technical literature and the media, such as NOPE (Not on Planet Earth) or BANANA (Build absolutely nothing anywhere near anybody). The NIMBY phenomenon carries an important additional meaning relative to LULU: it is used mainly to denote investments considered reasonable even by the opponents of the facility (a refuse incinerator, for example, which is necessary at national or regional level, and the absence of which could threaten waste management), who question only why it needs to be built in their backyards and not elsewhere (Sjöberg-Drottz-Sjöberg, 2001). 
In this chapter the social conflicts around the siting of Hungarian waste management facilities will be introduced and discussed. In the following section a general overview on the environmental conflicts of the transition period is given, and then in section 3 the research methodology is presented. Section 4, 5 and 6 deal with concrete mini case studies on siting conflicts. In section 7 the case studies are discussed, while section 8 contains some conclusions.

\section{The transition and environmental conflicts in Hungary}

The communist regimes of Central and Eastern Europe collapsed in 1989 enabling the set up of new democracies bringing the right for free speech, free elections, market economy, etc. to these countries. Post-communist societies had to learn to exploit the opportunities inherent in the newly established political and economic systems. Among many revelations, people began to understand what participation in local politics meant, how they could articulate their opinion in the local political arena, or how they were able to veto certain undesired decisions in regional and municipal level. Although transition in Central and Eastern European countries happened with different pace and intensity, Hungary definitely was one of the countries that adopted the new institutions the most rapidly at the beginning of the political transformation. The history of environmental decision making is an emblematic example of this learning process.

\subsection{Siting conflicts as a form of anti-communist movements}

Hungarian research focusing on environmental decisions began in the 1980s. The most important case of the era was the conflict concerning the construction of the BonsNagymarosi Dam, but the siting of the hazardous waste incinerator in Dorog also provoked many disputes (Faragó et al., 1989). These cases highlighted an important aspect of the situation in Hungary: they culminated at a historical moment which defined their further fate. The dam was a symbol of political power threading through everything of the totalitarian party regime (Fleischer, 1993). Protest against the dam was obviously a way to demonstrate against the regime, and hence the conflict acquired a connotation that was different from that of the typical Western European and North American conflicts. By the end of the eighties, it had become impossible to prevent the population from expressing its opinion on environmental decisions. One of the most important features of the siting conflicts at the time of transition, namely their dynamically changing institutional, political and social environment (something that existed hardly or not at all in Western European research) may reinforce our belief that the social institution systems (or their absence) have a major influence on the course of progress of social conflicts of this type.

The case of Bös-Nagymaros, however, highlighted many other factors as well. Firstly, it turned out that the tug of war of the actors of the central political power often manifests itself in specific cases and overrides expert considerations. Secondly, since the different positions ought to have been reconciled with the contribution of Czechoslovakia and later on Slovakia, the conflict, quite severe anyway, acquired an international dimension. The case of the dam shed further shadows on the far-from-cloudless relationship of the two countries, laden with conflicts historically. The national governments often used the case of the Dam to achieve their own home policy targets, without making a real effort to come to a solution. Decades later a similar dilemma recurred in the form of the conflict provoked by 
the siting of the Rosia Montana (Romania) gold mine, when the Hungarian state took action as stakeholder of the case. ${ }^{1}$

The siting of the Dorog hazardous waste incinerator was another problem given excessive media coverage in the eighties. The case was present throughout the decade, and it differed from that of the Dam in that it displayed problems similar to the ones we encountered in the Western European and North-American literature. The plan of Köbánya Pharmaceutical Factory to site a hazardous waste incinerator in Dorog, near Budapest, met with strong opposition there. There were already several polluting plants in the town (the pharmaceutical factory, a power plant and a briquette plant), and these imposed a significant burden on its environmental status. The residents were afraid that a new polluting factory would worsen the already unfavourable health conditions. The fact that the protesters held out despite the compensation packages being offered raises several questions. Knowledge commanded by the population and the experts, respectively, proved to be very different, the same as their points of reference. Distrust between the parties and their different value systems deepened the conflict even further (for a more detailed description of the case, see Faragó et al., 1989). The problems encountered in Dorog were obviously the same as those indicated by the relevant international literature (further pollution of areas exposed to environmental hazards already, and its moral aspects; reservations concerning compensation, and differences in risk perceptions).

Viktória Szirmai's study inquiring into the Hungarian circumstances (Szirmai, 1999) devotes an entire chapter to the "environmental social conflicts of the transition period", in which the author proposes a conflict typology, investigates the role of conflicts, and presents prevention options (Szirmai, 1999). Szirmai assigns environmental conflicts to five groups: conflicts to protect the values of the natural environment, protests against specific environmental damages, environmental conflicts related to waste management, urban development interventions, and infrastructure investments. In this study I focus on the environmental conflicts related to waste management, especially facility siting.

\subsection{Facility siting and waste management}

The transition period experienced a lot of siting conflicts in Hungary, many of them were related to landfills, dumps, and other waste management facilities. Around the date of EU accession the largest items of the Hungarian environmental state budget were spent on creation of new waste management facilities mostly with EU co-funding. Many of the landfills that were created before the transition period became obsolete and most of them were not in accordance with actual EU regulations therefore new facilities were needed.

Although industrial waste production has significantly dropped since 1990, the municipal waste generation has been still a crucial issue in the country (Pomázi, 2010). (Of course, municipal solid waste represents a lot smaller proportion than industrial waste production.) Municipal solid waste is mainly utilized in landfills (more than $80 \%$ of the waste is

\footnotetext{
1 Since few scientific reflections exist so far on this case which met with such considerable press reaction, I shall refrain from its more detailed presentation and analysis here. However, it can be stated that several of the basic siting approaches appear in this case: investors and politicians arguing that the economically deprived region will prosper are opposed to the locals and the civil and other interest groups (the government included) concerned by the risks involved. As in the case of the BösNagymaros Dam, party policy skirmishes, this time Romanian ones have made their impact on the development of the conflict.
} 
transported to these facilities), some of them is incinerated (around 6\%), and the rest is recycled or composted (see Figure 1.).

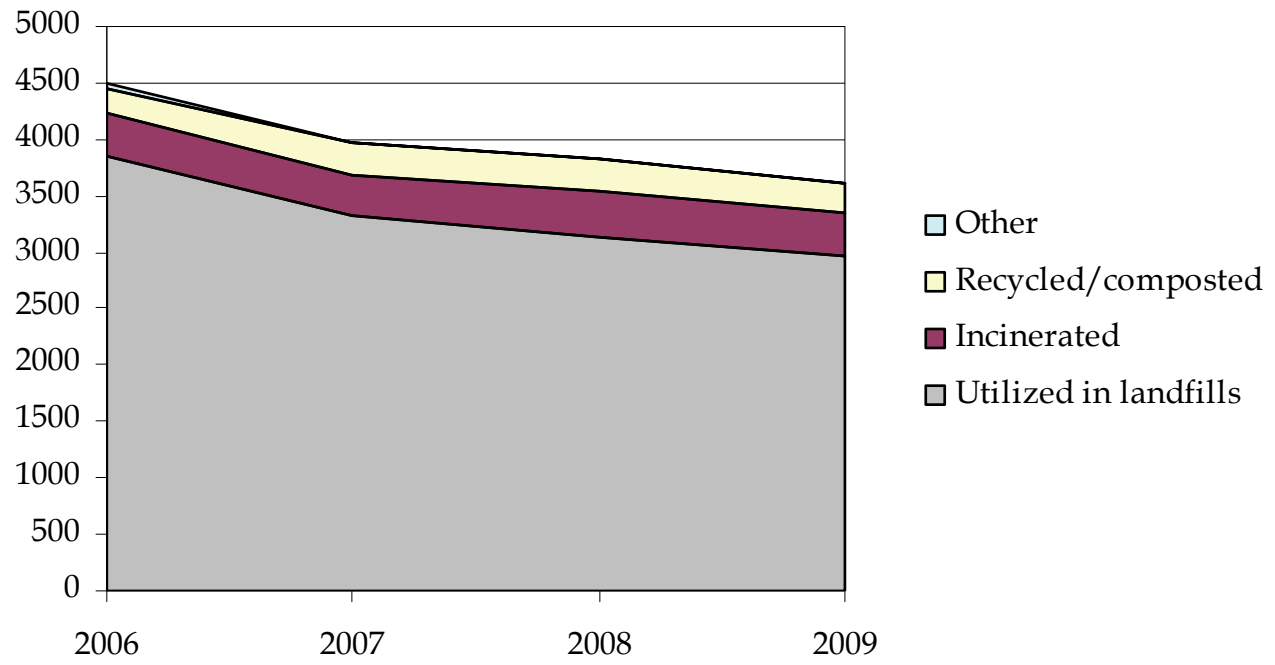

Fig. 1. Utilization of municipal solid waste (in thousand tons), source: HCSO

According to the relevant data, conflicts related to waste management issues mainly explode in minor settlements, with some exceptions (the cases that will be presented in this chapter are good illustrations for this phenomenon). In a previous study (Szántó, 2008) I pointed out that the settlements concerned are characterised by unemployment figures exceeding, occasionally excessively, the national average (the unemployment rate for example was thrice that of the national rate in Boda (County Baranya), considered a candidate for high level radioactive waste repository siting (see the case study later in this chapter), and in Liptód (in the same county), which rejected the siting of an envisaged waste disposal facility in 2000, it exceeded 30\%). The higher rate of pension recipients in these settlements suggests a high rate of the elderly. If we compare that with the low amount of personal income tax payments, it is quite clear that the settlements where waste-related social conflicts have occurred are probably the worst off, and they are characterised by rather low income and excessively high unemployment rates.

One could assume that a settlement like that would jump at the chance of a new investment, but the experience of specific cases is that poor incomes and high-level unemployment are not enough to make the residents approve an investment almost automatically if the envisaged facility is thought to be highly problematic. Nevertheless, it is no accident that investors tend to look for such sites. They probably believe that the prospects of job creation, local tax revenues and other forms of compensation will make the local stakeholders accept the hazardous facilities more easily.

\section{Methodology and data}

Research methodologies based on case studies are especially popular in the area of siting decisions laden with environmental conflicts, not only in Hungary, but also in many other 
parts of the world where such research is carried out. This is no accident. Researchers meet with many viewpoints in the context of most siting decisions. There are many perspectives, and many actors with different motives, which makes it difficult to design and carry out a well-operationalised quantitative research project. Research is further aggravated by the difficulty of separating the phenomenon under study from its context (if that is possible at all), and this is another circumstance which may encourage the researcher to apply qualitative research methodologies (and in particular case study method) (Yin, 1994).

\begin{tabular}{l|c|c}
\multicolumn{1}{c|}{ Case } & Type of waste & Years \\
\hline \hline $\begin{array}{l}\text { The North-east Pest County Waste Management } \\
\text { program }\end{array}$ & $\begin{array}{c}\text { solid municipal } \\
\text { waste }\end{array}$ & $2002-2004$ \\
\hline North-Balaton Region landfill & $\begin{array}{c}\text { solid municipal } \\
\text { waste }\end{array}$ & $2001-2010$ \\
\hline Battery waste recycling facilities & hazardous waste & $1985-2009$ \\
\hline Alternative fuel in the cement factory & hazardous waste & $2002-2005$ \\
\hline Low-level nuclear waste repository & nuclear waste & $1987-2009$ \\
\hline High-level nuclear waste repository in Boda & nuclear waste & $1995-$
\end{tabular}

Table 1. Case studies on social conflicts

In this chapter six mini case studies are presented in order to highlight the most important factors of social conflicts around siting decisions (Table 1. contains the selected cases and their most important attributes). All case studies have occurred in the last two decades, but some of them have roots in the communist era. The case studies were elaborated by using data from primary and secondary sources. In two cases, I relied mostly on case study interviews (the waste battery processing plant and the Vác cement factory cases), while the other case studies are based on mainly secondary data sources: articles from the national and local press, and studies made by other researchers. Of course, these mini case studies are rather illustrations of the most important symptoms and underlying causes of the Hungarian siting conflicts, and they cannot be considered as a comprehensive description of the conflicts of the last two decades.

\section{Solid waste facility siting}

A series of events having "enjoyed" extensive media coverage in the last two decades, mostly problems associated with regional solid waste disposal facilities. Larger cities (Budapest and county capitals) have been facing with the dilemma of the growing need for larger solid waste disposal facilities that were able to handle the solid waste output of these communities. The concept of regional landfills was popularized by the European Union; hence more and more depositories were planned in the country. The deposition-oriented solid waste management in Hungary obviously has been triggering more and more conflicts; more focus on prevention of waste generation would be able to mitigate the intensity of disagreements in the future.

\subsection{The North-east Pest county waste management program}

The social conflicts around the plans of the North-east Pest County Regional Waste Disposal Facility might have received the greatest publicity amongst all cases (Kiss, 2005). Of course, it is not surprising. Pest County is located in the heart of Hungary, has many ties with the 
country's capital Budapest, and is one of the most developed regions of the country. The events of the siting 'saga' were published in major newspapers and a comprehensive case study was elaborated about the siting process (Kovács \& Sándor, 2004). Since eight different villages were invited for accepting the waste management facility and all of them rejected the idea, the social conflicts were apparent even to the wider public. The rejections mostly came in a form of a veto: seven municipalities organized local referenda between 2002 and 2004, and the number of 'no' votes prevailed all the time.

The project originally was brought together by nine municipalities, but soon after that many other villages and towns joint to the consortium, finally 59 municipalities took part in the program. They planned to set up a new regional landfill that would handle the municipal solid waste of the region in Püspökszilágy. In this village waste management facilities were not unknown to the inhabitants; a low-level nuclear waste repository was already in operation there. In spite of this (or may be just because of this) the people of Püspökszilágy rejected the siting of a landfill in 2002. This was the first rejection that was followed by seven others; only one village - Valkó - would have supported the new site, but in this case the Ministry for Environment and Water vetoed the construction. Numerous stakeholder groups were involved in the siting process; inhabitants were supported by local and national environmental activist groups. The referenda showed that most people refused to have a waste management facility even with valuable economic compensations. Some critics claimed that rival waste management companies also enhanced the social conflicts since they opposed the new facility to be built from a business point of view (Kiss, 2005).

At the beginning of 2004 decision makers seeing the series of failures declared that there is no need for a large regional landfill, but modernization and expansion of existing facilities are sufficient for handling waste management problems of the county.

\subsection{The landfill of the North-Balaton region}

The North-Balaton waste management project similarly to the formerly introduced Northeast Pest County program had a long story in the first years of the new millennium. Veszprém with its 64,000 inhabitants plays a central role in the North-Balaton region; it is a cultural and economic centre. The increasing level of the municipal solid waste produced in the city worried city officials and they set up alternative courses of action in order to solve the problem. Their first idea was to expand the existing landfill of the city, however due to environmental reasons (the expanded landfill would have been built on a karstic area where no waste management facility can be placed) they had to give up this plan.

In Királyszentistván, which is located $10 \mathrm{~km}$ away from Veszprém, in 2001 a local referendum was held where the people of the tiny village (it has approximately 500 inhabitants) rejected the idea of a new regional landfill. The village seemed to be completely divided: the difference was so small that only ten votes decided. Other municipalities such as Ajka or Nagyvazsony earlier expressed that they would not welcome a noxious facility. However, the biggest disputes occurred in Szentgál where the people supported the siting of a new landfill, yet the neighbouring towns and villages heavily opposed the plans. Although the proposed facility would have been located officially in Szentgál, it would have been closer to the houses of the neighbouring municipalities; hence the negative consequences such as smell, environmental risks, increased traffic, etc. would have affected mostly them. Moreover, the project management team offered a compensation only for the locals of Szentgál (among others they offered a large sum of money for the renovation of the local elementary school), but the neighbours were neglected in this process. Although the people of Szentgál voted with yes in a referendum in 2003, the facility was never built there 
since the surrounding villages sued the investor company. By launching a litigation case the neighbouring villages created a dead end for the investment in Szentgál, since the construction could not have been started till the court did not make a decision. However, time pressure was enormous on the investors: they had to start building the site till 2006; otherwise the EU funding would have been lost.

Surprisingly enough the project management team after the fiasco, went back to Királyszentistván where the initiative was also a failure several years before. Nonetheless they implemented a more efficient strategy this time, they informed the people, and offered compensation for some neighbouring villages as well. During the second referendum the project was now supported, and the landfill was constructed, and finally opened in 2010.

\section{Social conflicts around hazardous waste siting}

As Table 1. highlighted the amount of hazardous waste has been decreasing recently; in 2008 it dropped bellow one million tons (Hungarian Central Statistical Office [HCSO], 2010). In this section two emblematic case studies will be introduced: (1) the brief history of the battery waste recycling facilities, and (2) the DDC Cement factory case where hazardous waste was utilized as an alternative fuel in the factory.

\subsection{The brief history of the battery waste recycling facilities}

The case of battery waste recycling facilities was discussed in several works, although each case study focused on a different stage of the events (Szirmai, 1999; Szántó 2010). This case, which has been dragging on for years, is the model example of Hungarian siting decisions, which exemplifies almost every one of the errors which can be committed by the decisionmakers, while also shedding light on the institutional, political and social factors influencing the siting of undesired facilities. A waste battery recycler is a typical NIMBY facility: the majority of the Hungarian society accepts its necessity in general terms (not to mention the international disapproval of shipping hazardous waste across the borders), but will show fierce local opposition to any specific siting attempt. Without a recycling facility the waste batteries must be exported to the neighbouring countries such as Austria and Slovenia and waste battery containing a valuable amount of lead are reused there.

In Gyöngyösoroszi, most objections concerned the prospective technology, beside the already high environmental load of the area; in Komló, the plan was condemned to failure by the counter-reactions of the adjacent settlements, which thought that they would share the burdens with the residents of Komló, whereas the benefits (local taxes, jobs) would go exclusively to the host settlement.

In Monok, a settlement at the gate of the Tokaj vine region, siting efforts failed because the local viticulturists felt that they threatened the reputation of the Tokaj wines, and did everything to kill the siting by their protest actions. Nevertheless, the inhabitants of Monok led by their mayor supported the idea to have a hazardous facility nearby since the new investment would have brought new jobs (around 200 employees would have been hired if the plant had been constructed) and growing tax revenues for the village. The unemployment rate in Monok exceeds the national figures significantly and the incomes of the local people just lag behind the one of more developed regions. Despite the differences in the underlying reasons, the success of the opposition was due in every case to forming a local coalition and to pooling the local interests (Szirmai, 1999) and, with the exception of Monok, the cases concerned confirmed again that investors like to site facilities at locations which have already hosted (voluntarily or under some constraint) a hazardous facility of 
some sort. A shift in favour of less resistance is, of course, reasonable, but it may be challenged on the ground of the failures and moral problems. Fear from stigmatisation is also discernible in the Monok case: the Tokaj farmers feared - probably with good reason that their products will be less marketable if it turns out that there is a waste battery recycling facility near the vine-growing region. ${ }^{2}$ The investor realizing the hostility of the potential host municipalities had to withdraw. This siting process seems to be a neverending story since the problem is not solved entirely yet even in 2011.

\subsection{Heating with alternative fuel - The case of the DDC cement factory}

Contrary to the above-described cases, the Vác cement factory case concerns the introduction of a new technology, not the siting of a new facility. Consequently, it differs in some essential respects from the previous ones. The envisaged introduction of hazardous waste incineration, however, can be conceived of as a special siting decision, and its reception was rather similar to the social conflicts triggered by the prospects of the new facilities of the battery waste recycling plants.

The hazardous waste incineration case of Duna-Dráva Cement (DDC) broke out in 2002. In November 2002, the company announced that the Central Danube Valley Environmental Protection Inspectorate authorised the factory to incinerate waste, including hazardous waste, as part of the cement manufacturing process. The permit applied to an annual 75 thousand tonnes of waste, a substantial part of which could be hazardous waste. The issue of alternative waste incineration had already been raised in the factory previously due to the many foreign experiences demonstrating the applicability and cost-effectiveness of this technology. The announcement was followed by protests on such scale as was unexpected to both the company management and the municipality. Some environmentalist groups disputed the professionalism of the environmental protection examinations, and in November 2002, the Hungarian Green Party started canvassing for signatures and in a short time it collected around 800 signatures from protesters. DDC and Vác municipality organised a forum together with the Vác Environmentalist Society, where it turned out that the factory had been experimenting with the incineration of various acid-resin-containing materials (spent oil, so-called Cemix and Mumix mixtures). (The factory was repeatedly accused of illegal waste-burning, but as a matter of fact they had had a permit for experimental acid resin burning valid until August 2001.) Several appeals were lodged against the resolution of the National Environmental Protection Inspectorate. Some objected to the incineration site being close to a school, and others found it injurious that the waste transports would probably increase the already quite heavy traffic on main road 2.

The Duna-Dráva Cement case culminated in 2003 and 2004. In January 2003, the National Inspectorate cancelled the waste incineration permit with reference to procedural errors, and obliged DDC to have a new impact assessment made. The Inspectorate was of the opinion that public hearings had to be held on cases like that, and the company had to make a full environmental impact assessment. Although the representatives of the company and of Vác municipality repeatedly emphasised that there were no professional arguments against the incineration of waste and in particular hazardous waste, and that the process was in full compliance with the environmental protection requirements, the opposition prevailed. After a

\footnotetext{
2 A local press organ published an article entitled "Chernobyl, too, was believed to be safe" in connection with the siting of the hazardous waste processing plant in Monok (Szántó, 2010). The envisaged investment was often compared to facilities which, although they did not have much in common with waste processing plants, evoked experiences which could stigmatise it.
} 
change in ownership in the nineties, the company tried to break with its previous negative image (the "one of the dirty dozen" nickname), but the image of the smoke-emitting cement factory and the awful dust it produced have never been forgotten by the locals.

In reaction to the protests, first of all an AdHoc Committee was formed to receive the complaints and observations of Vác residents and to forward them to the company management and, vice versa, to relay information obtained on the activity of the company to the population. The members of the six-strong committee included the heads of three Vácbased NGOs, the managing director of the factory, the environmental councillor of the municipality and a citizen of Vác. Although the members were independent, except for the factory managing director, the most prominent opponents were not represented on the committee. A toll-free hot line was installed in the Mayor's Office, where the locals could make announcements concerning the factory. Given the social pressure, the propositions of the civilians were taken into account in the full environmental impact assessment. This process took almost one year. In the meantime, the company came to realise that, to have the new technology accepted, it must open up towards society: they organised open days and pursued more intensive communication concerning the activity of the company and the waste incineration process itself. DDC's operation was shown on the local TV channels, and they, too, introduced a toll-free call number to receive questions and opinions. The company issued a newsletter called Monitor, which presented its activity and made public opinion polls to probe the attitude of the population to it. DDC enhanced its already quite impressive sponsoring activity: according to their own statistics, sponsoring expenditures doubled from 2002 to 2004.

The full environmental impact assessment was made public almost one year after the breakout of the events, in September 2003. On 24 February 2004, the Social Control Group was formed, the members of which were recruited mainly from the representatives of the previous AdHoc Committee: its president was the secretary of the Environmentalist Society of Vác (Váci Környezetvédelmi Egyesület), and its 13 members included the managing director of the Vác factory (who used to be on the AdHoc Committee), the representatives of certain civil organisations of Vác, the representatives of the municipalities of Vác and other settlements, and other opinion-leader personalities of the town. The Group was created pursuant to the decision of the mayor and the management of DDC, to ensure comprehensive social control over the cement factory and not in the least to build public trust in the factory. The opposition diminished considerably over the 18 months under study, but it could not be eliminated totally.

\section{Nuclear waste and siting}

Research in the 1980s revealed that the rejection rate was highest for facilities regarded as definitely hazardous, such as nuclear power plants and incinerators of hazardous waste (i.e. risk factors associated with relatively low probability of occurrence and catastrophic consequences) (Kasperson, 1986; Mitchell-Carson, 1986). In Hungary siting of radioactive waste repositories has not been such a hot issue as it was for example in the United States where in the last decades no nuclear waste management facility has been created. In this section - following the logics of the international literature - the low-level and high-level nuclear waste repositories will be introduced separately since these cases showed different patterns. 


\subsection{Low level radioactive waste repository}

The discussion complications of the siting of radioactive waste from the Paks nuclear power plant fits into the international trends analysing nuclear waste siting, as witnessed by a recent paper (Vári-Ferencz, 2006) which undertakes to summarise the events. Although the authors examine the siting of low-level waste and high-level waste separately, their conclusions apply to both areas.

The case of the Ofalu repository, which became a symbol of the inadequacy of the top-down decision-making mechanism of the socialist regime in the history of low- and intermediatelevel nuclear waste siting looking back on a longer past, has made it very clear that the technocratic approach and the consequent total exclusion of the population, a typical feature of environmental decision-making in the seventies and eighties, is untenable (Juhasz et al., 1993; Szíjártó, 1999). Ófalu as a location for the repository was proposed by the Paks Powerplant in 1987. The management of the plant did not inform the inhabitants who protested vehemently against the decision. As the Bós-Nagymaros Dam and the Dorog incinerator case the Ófalu case also a social conflict of the system change at the end of the eighties. Their protest was successful; the power plant had to withdraw.

The case of the selection of the Bátaapáti repository site was a relatively positive example of a new variant of environmental decision-making. That decision-making model was based on screening methods, which first screened the sites which did not conform to the geological and technological criteria, then studied the expected reactions of the population, followed by another screening of the candidate sites on the basis of that survey. This model is worth comparing with the procedure proposed by Swallow et al. (1992). They developed their model in connection with the construction of a solid waste landfill. In Stage 1, the potential sites conforming to certain minimum technical standards are selected; in Stage 2, the candidates are tested against some social requirements. Stage 2 results in a short list of candidates, of which one is selected in Stage 3 through the compilation of a compensation package. The investment site to be selected is the one that will be accepted by the population at the smallest compensation.

In the Bátaapáti case their three-stage model was replaced by a more limited decisionmaking procedure. In Hungary, the second stage was omitted (in the opinion of Vári \& Ferencz (2006), Bátaapáti is obviously not a suitable candidate site for a nuclear waste repository investment due to its agricultural and recreational profile), but the candidate host settlements were highly interested in the problems of the third stage (compensation specification, choice of the host settlement). Vári and Ferencz (2006) note that, after the systemic change the environmental decision-making model shifted quite noticeably from the technocratic to the market model; the investors realised the importance of compensation packages and upgraded their communication, often with the assistance of PR companies. The conflicts frequently turned the suffering stakeholders themselves against one another, and made the candidate settlements compete - due to their vulnerability and economic backlog - for hosting the facilities which in their opinion had detrimental effects (this, on the other hand, is in good agreement with the model of Swallow et al.).

\subsection{High level radioactive waste management}

Contrary to the previous section, there was no social debate and no definite standpoint was adopted concerning the social factors, in the case of Boda, a candidate for siting high-level nuclear waste. Back in 1986 the Paks Nuclear Power Plant made a contract with Soviet commercial agencies that the Hungarian high-level nuclear waste would be transported to the Soviet Union. Yet, after the Soviet Union collapsed this solution became fairly unstable therefore the power plant started to make research for the creation of a permanent high- 
level radioactive waste repository (Vári, 2009). The power plant began geological research in Boda in 1995 where the siltstone formation seemed to be suitable for placing high-level radioactive waste into the ground. Although this research was stopped for three years for political reasons in 2002 they were restarted and an underground laboratory was constructed in the following years.

Parallel with the research in Boda, a temporary facility to store spent nuclear fuel was established in Paks. It was another success story from the point of view of the Nuclear Power Plant, as the repository could be constructed near the Plant. The case is discussed in an earlier study by Vári (1996), in which she identifies the following factors as the pledge of success: (1) learning acquired from the fiascos of the Ófalu case, acquisition of high-level political support, (2) efficient PR activity, (3) shaky civil organisations on the opposite side, (4) material interest of the residents of Paks in the operation and even expansion of the power plant and (5) the population got accustomed to the proximity of the plant.

Boda is a small village with less than 500 inhabitants in a mountain region. In 1996 an association was formed with other five surrounding municipalities. This association socially controlled the research project, continuously informed the people and made decisions about the funding that was received from the Paks power plant (Vári, 2009). The communication had been intensive from the beginnings, a professional communication agency was assigned to create and implement an effective communication campaign. They regularly issued newspapers about the topic and they built an Information Office and Park in Boda. Interestingly, the residents of Boda seem to have become immune to the series of new communication efforts, and the issue of the high level radioactive waste repository has become less and less interesting to the public.

\section{Discussion}

Anna Vári, one of the most renowned Hungarian representatives of research programmes based on case studies devoted a decisive segment of her research activity to environmental conflicts related to siting and to the investigation of the related risk perceptions. Her works escorted the emblematic Hungarian environmental conflict cases, so to say: the scandals of the construction of the $\mathrm{M} 0$ ring road around Budapest; the severe controversies of the cyanide pollution conflicts in 2000, the open questions of the Ajka Power Plant investment and the problems concerning the siting of nuclear waste originating from Paks. Rather than providing a mere case description, the publications of Vári and her colleagues investigate the case in its broader context and draw more general conclusions from its progress. Vári identifies several reasons of the fiascos. Firstly, the objectives and the general plans have not been made clear. Secondly, in several cases, lack of alternatives put things on a forced track which was not acceptable for the stakeholders. It was observed on several occasions that the public was excluded, that no trust existed, and this has often generated tension even among the opponent civil organisations. The predominance of the technocratic approach (almighty planning staff), and the inadequate handling of the compensation packages (e.g. to "buy" the municipalities) has but intensified the opposition. Although foreign experts and PR firms were hired to help with the siting decisions and to communicate them, their success was at least dubious; in Vári's opinion, the foreign instruments and results have not been adapted to the Hungarian circumstances. These conclusions seem to apply not only to the motorway construction projects but, in a broader sense, to Hungarian siting decisions related to waste management facilities as well.

Risk communication has been a priority issue in Hungary, but there are different approaches as to the best manner of this communication. After transition, the new 
governments wanted to promote authentic information provision on siting matters by establishing the necessary legislative background, but it is often quite noticeable that this legislation is not enforced. Investors often neglect to inform local inhabitants about the potential drawbacks of the planned waste management facilities, and local people are seldom invited into the decision making process. The most serious deficiency of the communication policies was the predominance of one-sided communication. Despite every effort to develop bilateral communication and to integrate some external opinions (for example through a monitoring group in the Vác cement case), the companies rarely entered in a real dialogue, and the two sides often missed each other's points. It is not enough to organise fora and discussions: people must believe that the companies will pay heed and listen to their opinion. It takes two to have a dialogue - if one takes the initiative; the other must at least be sufficiently open and receptive.

The fate of the envisaged facility was decided by local referendum in a major part of the siting conflicts. This institution, if coupled with the right to veto, gives considerable power to the local community - in such cases, the host settlement exercises the proprietary rights. The body of representatives of the settlement, on the other hand, is bound only by the socalled binding ("decisive") local referenda, whereas a non-binding referendum will only give orientation to the management of the settlement. Several referenda were held in connection with the siting decisions discussed in the above case studies. A closer analysis of the cases, however, reveals that a negative referendum decision does not necessarily mean that the facility will not be built and, surprisingly, the inverse may also happen: the predominance of "yes" votes does not always lead to the installation of the facility. In Királyszentistván, although the siting of the regional waste repository was rejected twice (once at a public hearing and later on at a referendum), the disputed facility could in the end be built, since the locals voted "yes" on the third occasion. Note, however, that local referenda are often invalid, because less than half of the population goes to the polls. In such cases the decision-making right is usually transferred to the body of representatives.

In Hungary, most line policy issues acquire a very strong political connotation, and environmental issues are no exception. The siting decisions and the related social conflicts often have a political dimension (cf. the siting conflicts concerning the waste battery recycling plants (Szántó, 2010)). Politicians are important actors of social conflicts generated by siting decisions: in Vác for example, the Social Control Group was set up on the initiative of the mayor.

No wonder that the protests against the siting decisions are often espoused by the opposition parties, which obviously expect to gain political advantages thereby. Those in office ever usually support the investors in the hope that job creation and the growing tax and other revenues will strengthen their position in the management of the settlement and bring them extra votes at the subsequent elections. The central administration is usually also interested in the realisation of the siting decisions because, as in the case of the local managers, a successful investment may generate political capital for them. It would be exaggerated and an oversimplification to say that the siting cases are political games pure and simple, aimed at the acquisition of political power, but the attitude and behaviour of the government and the opposition politicians, respectively, in relation to the cement factories clearly diverge in line with their respective political orientations. Both parties must take this - the forceful intervention of politics in the siting conflicts - into account, as well as the fact that some will try to exploit the possibilities inherent in the roles played by the politicians.

The entry of party politics in the siting cases is, of course, not a surprising phenomenon, and certainly not a specific Hungarian feature. It is, however, worth separating the party 
political skirmishes from the political processes in the broader sense which shape the life of a settlement. The appearance of a new facility in a settlement may be a decisive affair, so it is quite understandable that it is part of the public discourse there and the various interest groups express their positions concerning the issue. It is a problem, on the other hand, if politics dominates these cases and drives the disputes into a party policy channel, because that makes it impossible to develop an open dialogue between the actors.

\section{Conclusion}

This chapter dealt with the development of the social conflicts around waste management facility siting in the last two decades of Hungary through case study research. It analyzed the most important cases of the last twenty years and explored what were the causes and implications of these social conflicts. Research methodologies based on case studies are especially popular in the area of siting decisions laden with environmental conflicts, not only in Hungary, but also in many other parts of the world where such research is carried out. This is no accident. In these cases there are many viewpoints, and many actors with different motives, which often provoke serious social conflicts.

The above review of the most important Hungarian case studies warrants the conclusion that the main roots of the research of siting conflicts are sociological ones. In Hungary, the sociological approach seems to be the most relevant of all the main trends manifesting themselves in the international technical literature. Almost every researcher states the domestic siting decisions cannot be discussed without speaking of the role of the social and political impacts. Let us risk the statement that this is a typical Central and Eastern European, rather than specifically Hungarian, phenomenon. The fact that transition and the surge in environmental conflicts occurred at the same historical moment anticipated the lead role of the sociological approach beside the psychological and economic ones in the analyses in these countries. The cases of the past years, on the other hand, highlight that community information programmes, especially the ones deploying PR means, sometimes manage to convince the locals that the given facility implies no special hazards to them. These techniques, however, cannot replace the participative methodologies recommended to date by most Western European and American researchers of the topic (Vári, 1997).

\section{References}

Faragó, K.; Vári, A. \& Vecsenyi, J. (1989). Not in My Town: Conflicting Views on the Siting of a Hazardous Waste Incinerator. Risk Analysis, Vol.9, No.4, (December 1989), pp. $463-$ 471, ISSN 1539-6924

Fleischer, T. (1993). Jaws on the Danube: Water Management, Regime Change and the Movement Against the Middle Danube Hydroelectric Dam. International Journal of Urban and Regional Research, Vol.17, No.3, (September 1993), pp. 429-443, ISSN $1468-2427$

Hungarian Central Statistical Office [HCSO] (2010). A települések infrastrukturális ellátottsága, Statisztikai tükör, Vol.4, No.114, (November 2010), pp. 1-5.

Juhász, J.; Vári, A. \& Tölgyesi, J. (1993). Environmental Conflict and Political Change: Public Perception on Low-level Radioactive Waste Management in Hungary, In. Environment and Democratic Transition, Vari, A. \& Tamas, P. (Eds.), 227-248, Kluwer Academic Publishers, ISBN 978-0792323655, Dordrecht, The Netherlands 
Kasperson, R. E. (1986). Hazardous Waste Facility Siting: Community, Firm, and Governmental Perspectives, In. Hazards: Technology and Fairness, White, R. M. (Ed.), 118-144, National Academies Press, ISBN 978-0309036443, Washington D. C., USA

Kiss, G. (2005). NIMBY vagy BANANA? Egy hulladékgazdálkodási beruházás társadalmi megítélése, Conference on transition in Central-Europe, Győr, Hungary, December, 2005, Available from

http://www.sze.hu/etk/_konferencia/publikacio/Net/eloadas_kiss_gabriella.doc

Kovács, J. \& Sándor, Cs. (Eds., 2004): Közösségi részvétel a hulladékgazdálkodási döntéshozatalban, Research Report, Available from http://www.emla.hu/alapitvany/03-04/hulladek.pdf

Lesbirel, S. H. (2003). Markets, Transaction Costs and Institutions: Compensating for Nuclear Risk in Japan, Australian Journal of Political Science, Vol.38, No.1, (March 2003), pp. 523, ISSN 1036-1146

Mitchell, R. C. \& Carson, R. T. (1986). Property Rights, Protest, and the Siting of Hazardous Waste Facilities, The American Economic Review, Vol.76, No.2, (May 1986), pp. 285-290, ISSN 0002-8282

Pomázi, I. (2010). Transition towards sustainability: myth or reality in Central and Eastern Europe, Hungarian Studies, Vol.24, No.1, pp. 99-126, (June 2010), ISSN 0236-6568

Popper, F. (1981). Siting LULUs, Planning, Vol.47, No.4, (April 1981), pp. 12-15, ISSN 0001-2610

Sjöberg, L. \& Drottz-Sjöberg, B. (2001). Fairness, risk and risk tolerance in the siting of a nuclear waste repository, Journal of Risk Research, Vol.4, No.1, (January 2001) pp. 75-101, ISSN $1366-9877$

Szántó R. (2008). A telepítési konfliktusok mintázata az elmúlt évtizedben, Társadalomkutatás, Vol.26, No.3, (September 2008), pp. 371-388, ISSN 0231-2522

Szántó, R. (2010). Environmental conflicts in Hungary - the case of the used battery reprocessing plants, In. Risks Challenging Publics, Scientists and Governments, Menoni, S. (Ed.), 259-266, CRC Press, ISBN 978-0415580724, London, UK

Szíjártó, Zs. (1999). Egy konfliktus etnográfiája: „laikusok” és „szakértők” vitája az ófalui atomtemető kapcsán. Tabula, Vol.2, No.1, (May 1999), pp. 52-87, ISSN 1419-3310

Szirmai, V. (1999). A környezeti érdekek Magyarországon, Pallas Stúdió, ISBN 978-9639207165, Budapest, Hungary

Swallow, S. K.; Opaluch, J. J. \& Weaver, T. F. (1992). Siting Noxious Facilities: An Approach That Integrates Technical, Economic, and Political Considerations, Land Economics, Vol.68, No.3, (August 1992), pp. 283-301, ISSN 0023-7639

Vári, A.; Kemp, R. \& Mumpower, J. L. (1991). Public Concerns about LLRW Facility Siting: A Comparative Study, Journal of Cross-Cultural Psychology, No.1, Vol.22, (March 1991), pp. 83-102, ISSN 0022-0221

Vári, A. (1996). A paksi atomerőmú kiégett fútőelemei átmeneti tárolójának telepítése. Társadalomkutatás, Vol.14, No.1-2, pp. 20-31, ISSN 0231-2522

Vári, A. (1997): A környezeti döntésekben való társadalmi részvétel és konfliktuskezelés fejlődése Magyarországon. In. Társadalmi és területi folyamatok az 1990-es évek Magyarországán, Kárpáti, Z. (Ed.), 273-295, MTA Társadalmi Konfliktusok Kutatóközpontja, ISBN 963-8310-07-3, Budapest, Hungary

Vári, A. \& Ferencz, Z. (2006). Fordulatok és kérdőjelek a radioaktív hulladékok hazai kezelésében. Társadalomkutatás, Vol.24, No.4, (December 2006), pp. 469-492, ISSN 0231-2522

Vári, A. (2009). Tiszta atomenergia? L'Harmattan, ISBN 978-9632361772, Budapest, Hungary

Yin, R. K. (1994). Case Study Research Design \& Methodology, Sage Publications, ISBN 9780761925538, London, UK 


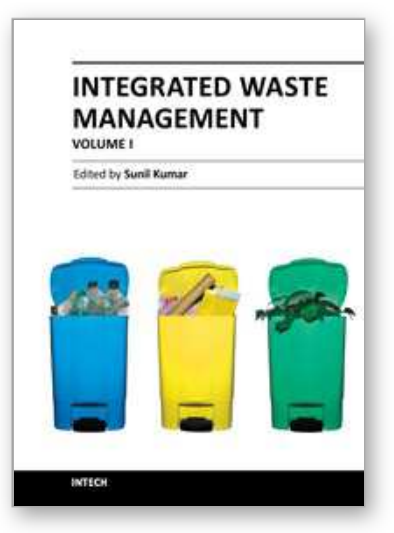

\author{
Integrated Waste Management - Volume I \\ Edited by Mr. Sunil Kumar
}

ISBN 978-953-307-469-6

Hard cover, 538 pages

Publisher InTech

Published online 23, August, 2011

Published in print edition August, 2011

This book reports research on policy and legal issues, anaerobic digestion of solid waste under processing aspects, industrial waste, application of GIS and LCA in waste management, and a couple of research papers relating to leachate and odour management.

\title{
How to reference
}

In order to correctly reference this scholarly work, feel free to copy and paste the following:

Szántó Richárd (2011). Waste Management Facility Siting and Social Conflicts - the Case of Hungary, Integrated Waste Management - Volume I, Mr. Sunil Kumar (Ed.), ISBN: 978-953-307-469-6, InTech, Available from: http://www.intechopen.com/books/integrated-waste-management-volume-i/waste-management-facilitysiting-and-social-conflicts-the-case-of-hungary

\section{INTECH}

open science | open minds

\section{InTech Europe}

University Campus STeP Ri

Slavka Krautzeka 83/A

51000 Rijeka, Croatia

Phone: +385 (51) 770447

Fax: +385 (51) 686166

www.intechopen.com

\section{InTech China}

Unit 405, Office Block, Hotel Equatorial Shanghai

No.65, Yan An Road (West), Shanghai, 200040, China

中国上海市延安西路65号上海国际贵都大饭店办公楼405单元

Phone: +86-21-62489820

Fax: +86-21-62489821 
(C) 2011 The Author(s). Licensee IntechOpen. This chapter is distributed under the terms of the Creative Commons Attribution-NonCommercialShareAlike-3.0 License, which permits use, distribution and reproduction for non-commercial purposes, provided the original is properly cited and derivative works building on this content are distributed under the same license. 